\title{
INVESTIGATION OF FOOD SUPPLEMENTS WITH PRESERVATIVE E211 (SODIUM BENZOATE) USING THIN-LAYER CHROMATOGRAPHY
}

\author{
(C) J. Gedziute, M. Marksa, A. Zevzikoviene, V. Skyrius, A. Zevzikovas
}

\begin{abstract}
Бензоат натрію часто обирають для виробництва рідких харчових добавок в якості консерванту через його антимікробну дію на велику кількість мікроорганізмів. Допустима кількість бензоату натрію в рідких харчових добавках становить до 2000 мг / л.

Методи. Для дослідження були обрані шість рідких харчових добавок, що містять бензоат натрію. Аналіз проводили з використанням скляних пластин CAMAG Twin Chamber, TLC Silica Gel 60 F254, cucтеми розчинників (хлороформ - етанол 9:1) і УФ-світла (254 нм) для візуалізації.

Результати. Методи візуалізації і системи розчинників були обрані з використанням еталонних розчинів. Бензоат натрію ідентифікували за допомогою $R f=0.76$, його кількість визначали шляхом калібрування. Для ідентифікації бензоату натрію в рідких харчових добавках була адаптована валідована методика. Кількість бензоату натрію аналізувалася у всіх досліджених об'єктах $і$ не перевищувало допустиму кількість.
\end{abstract}

Висновки. Вибрані методики підходять для якісної і кількісної очінки бензоату натрію в рідких харчових добавках

Ключові слова: тонкошарова хроматографія, харчові добавки, бензоат натрію, якісне і кількісне визначення

\section{Introduction}

Preservatives - a group of food additives which are used as antimicrobial agents to help keep the fresh product longer $[1,2]$. One of the representatives, sodium benzoate, is often chosen for the manufacture of liquid food supplements due to its antimicrobial effect against a large number of microorganisms and its better solubility in water than its precursor - benzoic acid [3-5]. The toxicology and adverse effects of benzoic acid and its derivatives and their safety levels have always been controversial [4]. Sodium benzoate has been found to inhibit the activity of D-amino acid oxidase, an enzyme that degrades D-serine, a highly prevalent amino acid in the brain [6]. Benzoic acid is slightly irritant to the skin and eyes, and sodium benzoate only to eyes [4]

\section{Formulation of the problem}

Currently, benzoic acid and a great variety of related compounds are generally recognized as safe substances and their use as additives in foods, cosmetics, pharmaceutical and hygiene products, is permitted by WHO and FDA [4]. But its amount should be controlled. Permissible sodium benzoate or benzoic acid amount in liquid food supplements is up to $2000 \mathrm{mg} / \mathrm{l}[4,7]$. Sodium benzoate can be added as preservative, but it can occur as common metabolite in plants (which are used for food supplements manufacture) too.

\section{Analysis of recent studies and publications}

Sodium benzoate is one of the most popular preservative in liquid food supplements, but as per analysis of literature sources there wasn't find any information about it's qualitative and quantitative analysis in them. There are some data about identification and quantification of sodium benzoate in solid forms of food supplements or food. \section{problem}

4. Allocation of unsolved parts of the general

After analysis of literature data it was observed that authors suggest to apply for analysis rarely used solvents (i.e. methylethylketone, n-methyl formate, etc.), which should be specially acquired for mentioned analysis $[8,9]$. This leads to additional expenses for laboratory. However, in methodics used in medicines analysis more commonly solvents are used [10].

\section{Formulation of goals (tasks) of Article}

It is important to develop new, fast, simple and precise methodics for analysis of sodium benzoate in food supplements and to adapt them to everyday practices in order to avoid possible adverse reactions due to exceeded permissible amount. The aim of experiment: to apply a thin-layer chromatography (TLC) methodology for qualitative and quantitative evaluation of sodium benzoate in liquid food supplements.

\section{Materials and methods}

The object of investigation: six randomly chosen liquid food supplements, containing sodium benzoate which is used as preservative. All analysed food supplements are available in Lithuanian pharmacies. Composition of each investigated object is presented in table (Table 1). 
Investigated food supplements qualitative composition, indicated by manufacturers

\begin{tabular}{|c|l|}
\hline $\begin{array}{c}\text { Investigated } \\
\text { object }\end{array}$ & \multicolumn{1}{c|}{ Compositions } \\
\hline FS_1 & $\begin{array}{l}\text { Glucose syrup, purified water, humectant sorbitol, aronia juice, raspberry flavoring, L-ascorbic } \\
\text { acid (vitamin C), D-alpha-tocopheryl acetate (vitamin E), zinc gluconate (zinc), aloe vera extract, } \\
\text { retinyl palmitate (vitamin A), sodium selenite (selenium), acidity regulator citric acid, preserva- } \\
\text { tive sodium benzoate. }\end{array}$ \\
\hline FS_2 & $\begin{array}{l}\text { Black currant juice, iron citrate, horsetail extract, big nettle extract, common birch leaf extract, } \\
\text { hyssop extract, buckhorn extract, lemon balm extract, honey, emulsifier carboxymethyl cellulose, } \\
\text { humectant glycerol, preservatives potassium sorbate and sodium benzoate. }\end{array}$ \\
\hline FS_3 & $\begin{array}{l}\text { Lactulose, grapefruit flavoring, acidity regulator citric acid, chinese rhubarb root extract, pre- } \\
\text { servative sodium benzoate, emulsifiers microcrystalline cellulose and sodium carboxymethyl- } \\
\text { cellulose. }\end{array}$ \\
\hline FS_4 & $\begin{array}{l}\text { Purified water, english hawthorn fruit dry extract, common valerian root dry extract, motherwort } \\
\text { herb dry extract, lemon balm leaf dry extract, preservatives potassium sorbate and sodium ben- } \\
\text { zoate, pyridoxine hydrochloride, pteroylmonoglutamic acid. }\end{array}$ \\
\hline FS_5 & $\begin{array}{l}\text { Serenzo } \text { TMamma-amino butyric acid, L-tryptophan, common chamomile petals dry extract, } \\
\text { pyridoxine hydrochloride (vitamin B } \text { ), emulsifiers microcrystalline cellulose and sodium carbox- } \\
\text { ymethylcellulose, preservatives potassium sorbate and sodium benzoate, sweetener sucralose, } \\
\text { black currant extract. }\end{array}$ \\
\hline FS_6 & $\begin{array}{l}\text { Purified water, humectant glycerol, common valerian dry extract, lemon balm dry extract, com- } \\
\text { mon hop dry extract, natural flavoring menthol, preservative sodium benzoate. }\end{array}$ \\
\hline
\end{tabular}

Reference and test solutions. Reference solutions $(1 \mathrm{mg} / \mathrm{ml})$ in methanol, prepared from benzoic acid standard (purity $99.5 \%$, Sigma-Aldrich) and sodium benzoate standard (purity $99.5 \%$, Sigma-Aldrich). Test solutions were prepared from liquid food supplements: $1 \mathrm{ml}$ of each individual food supplement was placed in different $5 \mathrm{ml}$ volumetric flasks and methanol was added to the measuring bar. Solutions were filtered through the polytetrafluoroethylene (PTFE) syringe filters with a diameter of $25 \mathrm{~mm}$ and pore sizes of $22 \mu \mathrm{m}$ (due to visible ballast substances).

TLC methodology: chromatographic analysis was performed using „CAMAG Twin Chamber“ $20 \times 20 \mathrm{~cm}$ chambers and chromatographic plates $20 \times 20 \mathrm{~cm}$ (TLC Silica Gel 60 F254 glass plates; Sigma - Aldrich, Germany). The samples on chromatographic plates were applied using a semi-automatic sampling applicator "CAMAG Linomat 5". Retention index $\left(\mathrm{R}_{\mathrm{f}}\right)$ values for the mixture component spots were determined using visualization device "CAMAG TLC Visualizer" and the software "VideoScan". For the solvent system preparation were used: ethyl acetate, methanol, concentrated ammonia, chloroform, ethanol. Visualization of chroma- tographic plates was performed using UV light lamp $(254 \mathrm{~nm})$ and Mandelin reagent, which was prepared by dissolution of $1.0 \mathrm{~g}$ of ammonium vanadate in $1.5 \mathrm{ml}$ of water with further dilution with sulfuric acid to $100 \mathrm{ml}$ [8].

Validation: For validation process following parameters has been chosen: specificity, repeatability, precision, limits (LOD and LOQ).

Analysis of food supplements: qualitative analysis was performed under the above mentioned conditions. 30 $\mu \mathrm{l}$ of each test solution was applied on the chromatographic plates.

For quantitative evaluation calibration curve was obtained (Fig. 1), using 6 prepared reference solutions, which concentrations were respectively: $1.0 \mathrm{mg} / \mathrm{ml}, 0.5$ $\mathrm{mg} / \mathrm{ml}, 0.25 \mathrm{mg} / \mathrm{ml}, 0.125 \mathrm{mg} / \mathrm{ml}, 0.0625 \mathrm{mg} / \mathrm{ml}$ and $0.03125 \mathrm{mg} / \mathrm{ml}$. Each point was measured 3 times. Quantity was calculated according to obtained formula:

$$
\mathrm{Y}=8.53 * 10^{3}+7.66 * 10^{4} * \mathrm{X}
$$

where: $\mathrm{Y}$ - peak area; $\mathrm{X}$ - amount of investigated substance.

The data were collected and analyzed using SPSS program

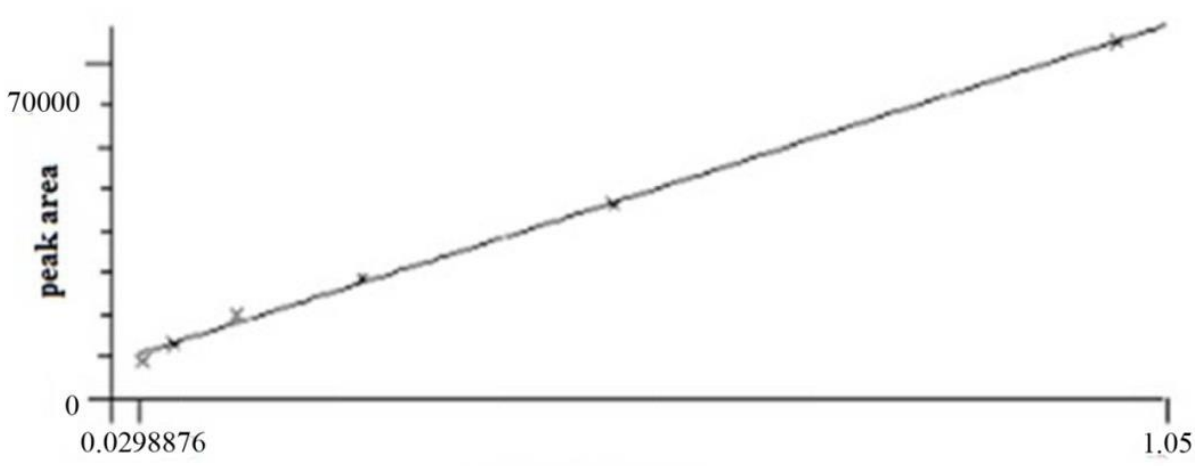

concentration

Fig. 1. Calibration curve 


\section{Results}

Methods for visualisation and solvent system were selected using the reference solutions. The performed experimental studies were assessed - which visualization method is suitable for identification. The visualization using UV-light was chosen (254 nm) as was mentioned by other authors too. Additionally during visualization process Mandelin reagent was applied, but identification has failed, because spots of the reference solutions were invisible. Selection of solvent system was based on the literature data. During experiments varied compositions of solvent systems noted in literature were used. Also, using different solvents and their proportions new solvent systems were investigated. After performed experiments the most suitable solvent system was selected (chloroform - ethanol 9:1). Other systems of solvents (ethyl acetate - methanol - concentrated ammonia 85:10:5, ethyl acetate, chloroform - methanol 9:1, etc.) weren't suitable because spots were indistinct or invisible and there wasn't possibility to identificate the analytes. After choosing the most suitable solvent system and visualization method the retention index value $\left(R_{f}\right)$ was determined. It was observed, that $R_{f}$ values of benzoic acid and sodium benzoate are the same, and is equal to 0.76 . Because of this reason, in latest experiments was used only one reference solution.

Before applying of this methodic for analysis of food supplements it was validated according to $\mathrm{ICH}$ Harmonised Tripartite Guideline [11]: specificity $\left(R_{f}=0.76\right)$, repeatability $(p<0,05)$, precision $(0,1 \%)$, limits (detection limit $-3.34 \mu \mathrm{g} / \mathrm{ml}$ and the limit of quantitation $-9.25 \mu \mathrm{g} / \mathrm{ml})$.

Qualitative evaluation was performed by introduction on the chromatographic plate reference solution of sodium benzoate and all 6 investigated food supplements containing sodium benzoate (Fig. 2).

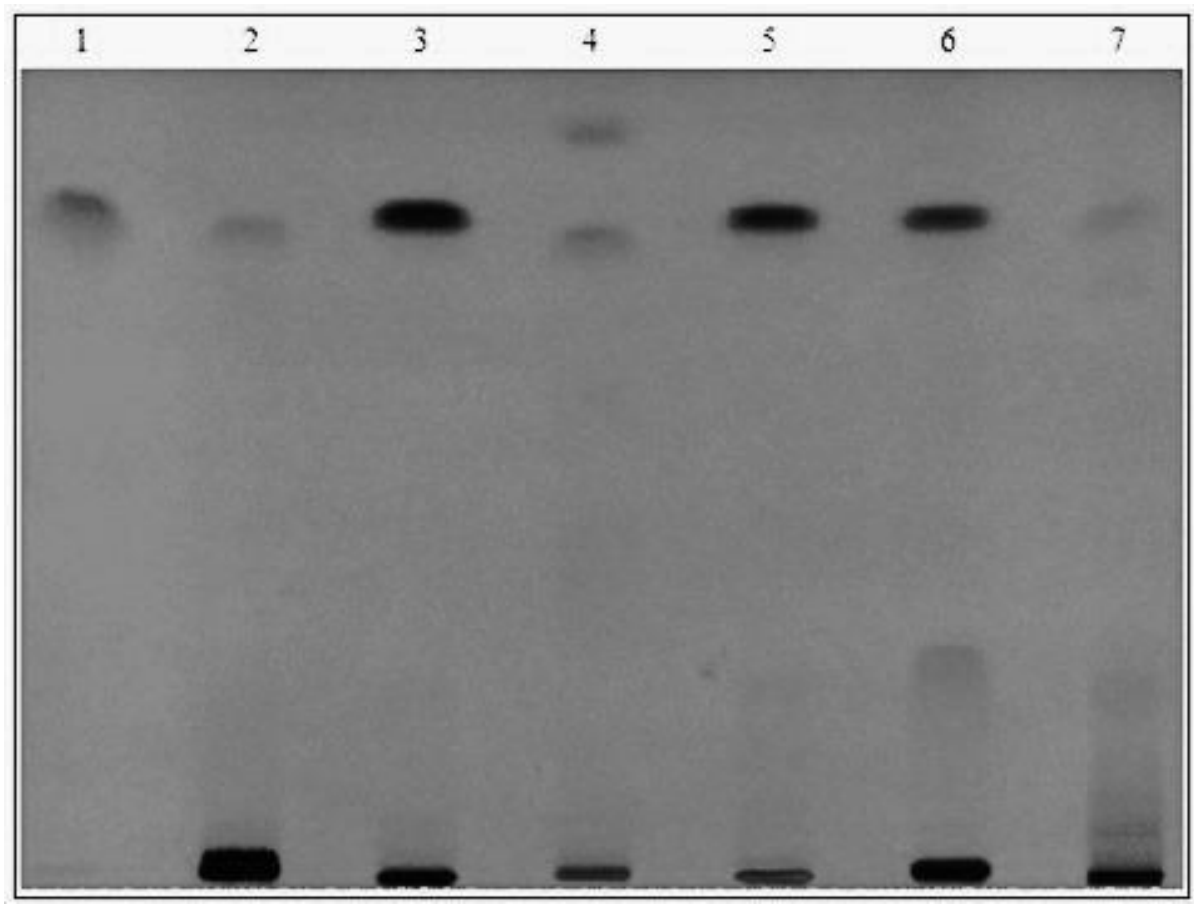

Fig. 2. TLC chromatogram ofanalysed food supplements (1 - reference solution, 2-7 food supplements)

Sodium benzoate in each food supplement was identificated according reference solution. In this experiement, not only sodium benzoate spots were visualized but also the spots of unidentified substances. It can be explained by the ballast substances fixation, which were also dissolved in methanol. The tests were repeated to assess the reliability of the applied methodology. Statistical data are presented in table (Table 2).

Table 2

Statistical investigated objects containing sodium benzoate $\mathrm{Rf}$ values evaluation

\begin{tabular}{|c|c|c|c|c|}
\hline Investigated object & Rf average & Standard deviation & Error & Confidence interval \\
\hline FS_1 & 0,844 & 0,003 & 0,0015 & $0,838-0,851$ \\
\hline FS_2 & 0,862 & 0,002 & 0,0009 & $0,858-0,865$ \\
\hline FS_3 & 0,831 & 0,002 & 0,0009 & $0,827-0,835$ \\
\hline FS_4 & 0,856 & 0,001 & 0,0007 & $0,853-0,859$ \\
\hline FS_5 & 0,862 & 0,002 & 0,0009 & $0,858-0,865$ \\
\hline FS_6 & 0,853 & 0,002 & 0,0009 & $0,849-0,857$ \\
\hline
\end{tabular}


The tolerances for the repeatability of all tested samples results do not exceed $0.05 \%$ limit, therefore the methodology is considered to be a reliable for qualitative evaluation of sodium benzoate in samples using TLC.

Quantitative evaluation. Following the qualitative determination of sodium benzoate in selected food supplements, the quantity of this substance in the chosen products was evaluated. After calibration curve obtainment, the amount of sodium benzoate in each food supplement was assessed:

$240 \mathrm{mg} / \mathrm{l}$

-FS_1 - $0.24 \mathrm{mg} / \mathrm{ml}$, which corresponds to

$1630 \mathrm{mg} / \mathrm{l}$

-FS_2 - $1.63 \mathrm{mg} / \mathrm{ml}$, which corresponds to $180 \mathrm{mg} / \mathrm{l}$;

-FS_3 $-0.18 \mathrm{mg} / \mathrm{ml}$, which corresponds to $1140 \mathrm{mg} / \mathrm{l}$
-FS_4 - $1.14 \mathrm{mg} / \mathrm{ml}$, which corresponds to
-FS_5 - $0.88 \mathrm{mg} / \mathrm{ml}$, which corresponds to $880 \mathrm{mg} / \mathrm{l}$;

-FS_6 - $0.09 \mathrm{mg} / \mathrm{ml}$, which corresponds to $90 \mathrm{mg} / \mathrm{l}$.

The determined amounts of sodium benzoate in investigated food supplements did not exceed the permissible level of use $-2000 \mathrm{mg} / \mathrm{l}$.

\section{Conclusion}

1. The most suitable chromatographic conditions were established: solvent system (chloroform - ethanol 9:1) and the UV-light $(254 \mathrm{~nm})$ for visualization for identification and quantification of sodium benzoate.

2. Validated methodics was adapted for analysis of sodium benzoate in liquid food supplements.

3. The amount of sodium benzoate in all investigated objects was analysed and did not exceeded the permissible amount $(2000 \mathrm{mg} / \mathrm{l})$.

\section{References}

1. Gultekin F., Doguc D. K. Allergic and Immunologic Reactions to Food Additives // Clinical Reviews in Allergy \& Immunology. 2012. Vol. 45, Issue 1. P. 6-29. doi: http://doi.org/10.1007/s12016-012-8300-8

2. Del Olmo A., Calzada J., Nutez M. Benzoic acid and its derivatives as naturally occurring compounds in foods and as additives: Uses, exposure, and controversy // Critical Reviews in Food Science and Nutrition. 2015. Vol. 57, Issue 14. P. $3084-3103$. doi: http://doi.org/10.1080/10408398.2015.1087964

3. Benzoic Acid Derivatives fromPiperSpecies and Their Antiparasitic Activity / Flores N. et. al. // Journal of Natural Products. 2008. Vol. 71, Issue 9. P. 1538-1543. doi: http://doi.org/10.1021/np800104p

4. Del Olmo A., Calzada J., Nunez M. Benzoic acid and its derivatives as naturally occurring compounds in foods and as additives: Uses, exposure, and controversy // Critical Reviews in Food Science and Nutrition. 2015. Vol. 57, Issue 14. P. 3084-3103. doi: http://doi.org/10.1080/10408398.2015.1087964

5. Preservatives in liquid pharmaceutical preparations / Boukarim C. et. al. // Drug Testing and Analysis. 2009. Vol. 1, Issue 3. P. 146-148. doi: http://doi.org/10.1002/dta.28

6. COMMISSION REGULATION (EU) No 1129/2011 of 11 November 2011 amending Annex II to Regulation (EC) No 1333/2008 of the European Parliament and of the Council by establishing a Union list of food additives // Official Journal of the European Union. 2011. URL: http://eur-lex.europa.eu/legal-content/EN/TXT/PDF/?uri=CELEX:32011R1129\&from=LT

7. Beezhold B. L., Johnston C. S., Nochta K. A. Sodium Benzoate-Rich Beverage Consumption is Associated With Increased Reporting of ADHD Symptoms in College Students // Journal of Attention Disorders. 2012. Vol. 18, Issue 3. P. $236-241$. doi: http://doi.org/10.1177/1087054712443156

8. Khan S. H., Murawski M. P., Sherma J. Quantitative High Performance Thin Layer Chromatographic Determination of Organic Acid Preservatives in Beverages // Journal of Liquid Chromatography. 1994. Vol. 17, Issue 4. P. 855-865. doi: http://doi.org/10.1080/10826079408013373

9. Ma Y., Yeung E. S. Determination of components in beverages by thin-layer chromatography: An undergraduate analytical chemistry experiment // Journal of Chemical Education. 1990. Vol. 67, Issue 5. P. 428-429. doi: http://doi.org/10.1021/ed067p428

10. Moffat A. C., Osselton M. D., Widdop B. Clarke‘s Analysis of Drugs and Poisons. London: Pharmaceutical Press, 2011. 2473 p.

11. ICH Harmonised Tripartite Guideline. Validation of Analytical Procedures: Text and Methodology. URL: https://www.ich.org/fileadmin/Public_Web_Site/ICH_Products/Guidelines/QualiQu/Q2_R1/Step4/Q2_R1_Guideline.pdf

Дата надходження рукопису 24.05.2018

Juste Gedziute, Postgraduate Student, Department of Analytical and Toxicological Chemistry. Lithuanian University of Health Sciences, Sukilèlių str., 13, Kaunas, Lithuania, 50162

E-mail: justeg22@gmail.com

Mindaugas Marksa,. Lecturer. Department of Analytical and Toxicological Chemistry, Lithuanian University of Health Sciences, Sukilèlių str., 13, Kaunas, Lithuania, 50162

E-mail: minzedas@gmail.com

Augusta Zevzikoviene, PhD, Associate Professor, Department of Analytical and Toxicological Chemistry. Lithuanian University of Health Sciences, Sukilèlių str., 13, Kaunas, Lithuania, 50162

E-mail: augustazev@gmail.com

Vaidas Skyrius, PhD, Associate Professor, Department of drug Technology and Social Pharmacy, Lithuanian University of Health Sciences, Sukilèliu str., 13, Kaunas, Lithuania, 50162

E-mail: vaidas.skyrius@1smuni.lt

Andrejus Zevzikovas, PhD, Associate Professor, Department of Analytical and Toxicological Chemistry, Lithuanian University of Health Sciences, Sukilèlių str., 13, Kaunas, Lithuania, 50162

E-mail: andrejuszevzikovas@gmail.com 